\title{
PENYULUHAN DAN PEMBINAAN MANFAAT DAN BUDIDAYA TANAMAN SURGAWI
}

\author{
Nazwirman, Juniarti, dan Zainal Zawir Simon \\ Magister Manajemen Universitas YARSI, Fakultas Kedokteran Universitas YARSI \\ Juniarti@yarsi.ac.id
}

\begin{abstract}
This activity aims to provide knowledge about the various benefits of heavenly plants and planting patterns of date (Kurma), tin and bidara cultivation for cleaners in the Banjar Wijaya housing complex in Tangerang City. The activity was given in the form of counseling and coaching about the benefits and ways of cultivating heavenly plants. As a result, as many as 12 participants increased their knowledge significantly both about the method of utilization and cultivation. This activity was at once a socialization of the theory and practice of plant benefits contained in the Qur'an and the Sunnah of the prophet with a sharing and accompaniment approach.
\end{abstract}

PENDAHULUAN

Tanaman surgawi ini mempunyai manfaat dan sudah dibuktikan (Bentrad, 2017), namun pengetahuan masyarakat masih cukup rendah. Gerakan "back to nature" saat ini kembali ditingkatkan untuk mendapatkan obat alami yang bersumber dari tanaman. Pemanfaatan tanaman yang berasal dari Al Qur'an dan Sunnah nabi antara lain terdapat 60 ayat yang menceritakan tentang buahbuahan dan bagian tanaman dalam $\mathrm{Al}$ Qur'an.

\section{Pertama Kurma buah}

menawarkan kelezatan dan memiliki banyak khasiat yang terbukti secara ilmiah. Buah ini sangat kaya akan nutrisi yang baik untuk tubuh. Kurma mengandung sejumlah vitamin, mineral, dan serat. Kurma juga memiliki antioksidan yang dapat menangkal sejumlah penyakit. Kurma kering mengandung lebih banyak kalori yang berasal dari karbohidrat. Phon Kurma ini juga dapat dibudidayakan di Negara tropis seperti Indonesia.

Kedua buah tin, yang sering diandalkan saat zaman rasulullah S.A.W yang memiliki banyak khasiat dan gizi. Buah Tin memiliki kandungan rendah kalori dan tidak memiliki kandungan lemak serta memiliki manfaat seperti daun dipercaya dapat menurunkan gula darah sehingga sangat baik untuk dikonsumsi oleh pasien diabetes. Pohon ini dapat dibudidayakan di Inonesia. Ketiga Bidara, pohon yang asli dari Timur Tengah yang memiliki iklim hangat, namun tetap bisa 
dibudidayakan di Indonesia. Bidara adalah tanaman surga yang ditakuti jin, dan menyimpan berbagai manfaat untuk manusia.

\section{KHALAYAK SASARAN}

Kecamatan Pinang merupakan salah satu dari 13 kecamatan yang ada di Kota Tangerang. Luas Kecamatan ini sebesar 21, $59 \mathrm{~km}^{2}$ dengan jumlah penduduk 192.061 jiwa (tahun 2015), sehingga kepadatan penduduknya 8.896 jiwa per $\mathrm{km}^{2}$. Wilayah ini terdiri dari 11 kelurahan dengan kisaran jumlah penduduk antara 3.206 sampai 37.924 jiwa. Kelurahan yang wilayahnya cukup luas ialah Cipete $\left(2,17 \mathrm{~km}^{2}\right)$. Sebagian wilayah kelurahan ini terdapat Perumahan Banjar Wijaya. Dari hasil observasi komplek perumahan ini yang memiliki cluster-cluster dan fasilitas umum yang sebagian besar ditanami pohon lindung dan buah. Rata-rata dalam cluster perumahan ada 9 (sembilan) orang tenaga keamanan (security) serta minimal 4 (empat) orang tenaga kebersihan. Umumnya nereka berpendidikan dan penghasilan yang rendah. Untuk tenaga kebersihan ratarata mereka mendapatkan Rp 1.4 juta perbulan dan jam kerja lebih kurang 5 jam perhari. Seluruh petugas kebersihan sudah berkeluarga dan rata-rata memiliki 2 (dua) orang anak bahkan ada yang sudah memiliki cucu. Tentunya dengan pendapatan sebanyak itu kurang mencukupi.

Besarnya manfaat tanaman surgawi dan rendahnya pemanfaatan tanaman serta pembudidayaan tersebut di tengah masyarakat mendorong dilaksanakannya Pengabdian pada Masyarakat yang dimungkinkan menjadi pilot project sosialisasi penanaman serta pembudidayaan tanaman surgawi pada tenaga kebersihan, selain itu untuk meningkatkan produktivitas usaha mereka sehingga dapat meningkatkan pendapatan (Rostini et al., 2017).

\section{METODE PELAKSANAAN}

Metode pelaksanaan yang digunakan oleh kelompok pengabdian masyarakat adalah sosialisasi tentang manfaat dan metode pendampingan penanaman dan budidaya tanaman surgawi. Bagian dari kegiatan adalah memberikan penyuluhan dan praktik tentang manfaat dan budidaya tanaman surgawi. Tujuan kegiatan yaitu untuk memberikan informasi untuk meningkatkan pengetahuan dan pengalaman peserta dengan metode 
mempengaruhi prilaku masyarakat. Kegiatan ini melibatkan beberapa pihak yaitu dosen Sekolah Pascasarjana Universitas YARSI selaku pihak yang akan menjalankan peran memberikan pemahaman terkait manfaat dan pendampingan pembudidayaan tanaman surgawi. (2) Tenaga kebersihan tiap-tiap cluster di perumahan Banjar Wijaya Kota Tangerang

Secara khusus ada 3 (tiga) tahapan evaluasi yang dilakukan yaitu:

1) Evaluasi tahap pertama yaitu sosialisasi pemanfaatan dan budidaya dan tanaman surgawi.

2) Melihat dampak sosialisasi terhadap peningkatan pengetahuan tenaga kebersihan perumahan Banjar Wijaya sebelum dan sesudah sosialisasi (pre dan postest).

3) Memantau budidaya penanaman bibit tanaman surgawi secara berkala.

\section{HASIL DAN PEMBAHASAN}

Penyuluhan dengan memberikan penjelasan dan kepada peserta tentang manfaat-manfaat tanaman surgawi. Tanaman buah-buahan yang secara khusus namanya disebutkan dalam AlQuran seperti kurma (Phoenix dactylifera), Tin (Ficus carica), Zaitun
(Olea europaea) yang mengandung banyak manfaat. Buah-buahan tersebut disebutkan secara khusus dalam AlQur'an yang berarti bukanlah tanaman sembarang dan buah biasa seperti disebutkan pada ayat Al-Qur'an (QS An-Nahl: 11, Maryam: 24-26). Maka pastilah tanaman buah tersebut mengandung lebih banyak manfaat. Bukan dari buahnya saja tetapi bahkan mungkin semua bagian dari tanaman buah itu.

\section{Tanaman buah kurma (Phoenix dactylifera)}

Buah kurma merupakan produk dari pohon palem yang masuk dalam keluarga Arecaceae. Kurma (Phoenix dactylifera) memiliki ukuran tinggi pohon berkisar 15-25 meter dan panjang daun mencapai kisaran 3-5 meter. Pohon diduga berasal dari Teluk Persia yang buahnya memiliki warna kecoklatan dan berbiji tunggal. Pohon kurma ini merupakan salah satu tanaman tertua yang masih terpelihara didunia. Kurma berguna untuk pengobatan beberapa penyakit ataupun sebagai bahan makanan untuk mengatasi kelaparan (QS Maryam, 2526). Manfaat lain buah kurma untuk menjaga kesehatan tidak terlepas dari kandungan zat-zat nutrisi yang 
dimilikinya. Berdasarkan zat-zat nutrisi yang terkandung dalam buah kurma beberapa manfaat buah kurma yaitu: dapat mengatasi kontipasi, menunjang kesehatan dan kekuatan tulang, mengatasi ganguan usus, membantu mengobati anemia, menanggulangi alergi, membantu dalam proses pemulihan penyakit demam berdarah, dll (USDA National Nutrient data base)(https://ndb.nal.usda.gov/).

\section{Tanaman buah Tin (Ficus carica)}

Maha Suci Allah yang telah menciptakan buah tin dimana terbukti secara ilmiah mengandung manfaat yang sangat luar biasa. Qur'an Surat Ali-Imran ayat 191 bahwa Allah tidak menciptakan sesuatu di alam semesta ini dengan sia-sia: Orang-orang yang mengingat Allah sambil berdiri atau duduk atau dalam keadaan berbaring, dan mereka memikirkan tentang penciptaan langit dan bumi (seraya berkata): "Ya Tuhan kami, tiadalah Engkau menciptakan ini dengan sia-sia, maha suci engkau, maka peliharalah kami dari siksa neraka".

Nama "Tin" (bahasa Arab), juga dikenal dengan Ara (buah ara/pohon ara) sedangkan dalam bahasa Inggris disebut fig. Tin (Ficus carica L.) merupakan salah satu tanaman yang disebutkan dalam Al-quran sebagai tumbuhan yang diberkahi dan berasal dari Asia Barat. Tumbuhan ini dapat dimakan sehingga tidak heranlah jika buah tin disebut makanan Nutraseutikal (functional food), karena buah tin bukan sekedar mengandung zat-zat yang berkhasiat, tetapi sebagai penjaga tubuh dan mampu mencegah serangan penyakit-penyakit tertentu. Lembaga Penasehat Buah Tin di California (California Fig Advisory Board) telah mengatakan buah tin sebagai "Nature's most nearly perfect fruit", artinya buah yang hampir mencapai tahap kesempurnaan secara keseluruhan.

Beberapa khasiat dari daun tin bagi kesehatan yaitu: (1) Menguatkan tulang; disamping buahnya yang banyak dimanfaatkan di dunia medis, ternyata daunnya juga mengandung kalsium tinggi sehingga mampu memperkuat tulang. (2) Menangkal penyakit kanker; daun tin mengandung antioksidan tinggi yang mampu menangkal radikal bebas yang masuk ke sel-sel dalam tubuh. (3) Menurunkan gula darah; pemanfaatan mengobati gula darah karena mengandung senyawa aktif yang memiliki kesamaan kadar dengan hormon insulin. Hormon insulin ini berfungsi menurunkan kadar gula darah 
dalam tubuh. (4) Mengobati penyakit batu ginjal; mengandung senyawa yang bernama saponin dan alkaloid, kedua senyawa tersebut bermanfaat sebagai diuretik masalah batu ginjal. (5) Menyembuhkan rasa nyeri pada badan karena mengandung senyawa flavonoid ialah luteolin dan quercetin. Kandungan yang memiliki sifat antiinflamasi yang bermanfaat dalam menyembuhkan rasa nyeri yang diderita. (6) Meningkatkan sistem kekebalan tubuh; jika dikonsumsi mampu memproduksi limfosit dan antibodi dalam tubuh sehingga tubuh mampu menangkal radikal bebas yang masuk dan mengandung senyawa anti virus, anti bakteri dan anti jamur sehingga tubuh tetap terjaga kekebalannya.

\section{Tanaman buah Bidara}

Bidara (Ziziphus mauritiana) merupakan sejenis pohon kecil penghasil buah yang tumbuh di wilayah kering. Bidara (Sidr) disebutkan di beberapa surah dalam Al-Qur'an, yaitu: (1). QS.34. Saba':16 (sebagai pohon bidara yang sedikit jumlahnya (sidrin qolil)) (2). QS.56. Al-Waqiah:28 (sebagai pohon bidara yang tak berduri (sidr makhdud)) (3). QS.53. An-Najm: 13-16 (sebagai pohon bidara perbatasan akhir (sidratul muntaha) dan Pohon bidara yang diliputi (sidrata ma yaghsya)).

Selain disebutkan di dalam AlQur'an juga pohon ini terdapat anjuran penggunaannya di dalam hadits. Bidara digunakan dalam berbagai prosesi ibadah seperti daunnya disunnahkan untuk digunakan ketika mandi wajib bagi wanita yang baru suci daripada haid (HR. Muslim), memandikan jenazah dan menghilangkan najis dari tubuh mayat, jenazah disarankan dimandikan dengan air yang dicampur daun bidara (HR. Bukhari - Muslim), juga kadang kala dipergunakan dalam proses Ruqyah untuk mengobati orang yang kesurupan.

\section{Budidaya Pohon Kurma}

Kurma merupakan sejenis tanaman yang dapat beradaptasi di cuaca kering dan bahkan sangat panas. Kurma juga sangat fleksibel terhadap macam-macam tanah dan juga tanah basah.

Menanam kurma membutuhkan cuaca pada musim panas yang panjang. Ini diperlukan dari masa penyerbukan hingga pada masa penen, hanya saja tetap membutuhkan air yang cukup agar pohon kurma mampu melakukan pembuahan. Habitat kurma adalah padang pasir yang tandus, maka 
sebagian orang akan berfikir bahwa kurma tidak bisa ditanam di daerah lain yang memiliki iklim yang berbeda. Namun nyatanya, kurma telah dapat ditumbuhkan di berbagai negara seperti Thailand dan bahkan di Indonesia. Beberapa petani bahkan memiliki pohon - pohon kurma dengan buah yang banyak. Secara ekonomis hasil panen dari pohon kurma sebagian besar menjadi sumber penghasilan. Produksi kurma selama 40 tahun terakhir meningkat sebanyak 2,9 kali lebih, sedangkan penduduk dunia meningkat dua kali lipat. Indonesia merupakan salah satu negara yang mengimpor kurma dari berbagai negara lain yang mencapai lebih dari 17,3 ribu ton dengan total nilai mencapai 19 juta dollar

(https://money.kompas.com/read/2019/

04/15). Setiap tahun angka impor kurma selalu naik, hal ini dikarenakan peminatan masyarakat terhadap kurma semakin banyak (BPS, 2018).

Ada langkah- langkah budidaya agar kurma dapat tumbuh dan bisa berkembang hingga berbuah (https://sentrabudidaya.com/tipsbudidaya-cara-menanam-kurma/). Langkah-langkah penanaman kurma yang dianjurkan: (1) Dapat dibudidayakan dengan proses degeneratif atau melalui perkecambahan biji. Biji kurma dapat diperoleh dengan memesan dan membeli bibit unggul dari petani maupun mengumpulkan secara manual dari buah kurma. (2) Lakukan pemindahan bibit kedalam pot atau polibag jika telah terjadi pertumbuhan dapa biji. Jika menggunakan metode tisu basah, tunggulah sekitar 14 hari (pertumbuhan tunas dan akar telah mencapai panjang 5 hingga $10 \mathrm{~cm}$ ), lalu pindahkan kedalam media tanam. Sedangkan yang langsung disemaikan di media tanam, lihatlah perkembangan bibit (hingga mencapai tinggi sekitar 20 hingga $30 \mathrm{~cm}$ ) dan pindahkan ke media tanam yang lebih besar (3) Setelah bibit kurma dianggap besar dan mulai bisa untuk di tanam. Dalam proses penanaman, harus diberi jarak yang cukup (5-6 m per bibit kurma) agar menghindari adanya perebutan zat-zat yang diperlukan. Setidaknya membutuhkan ukuran lubang antara 50 sampai $60 \mathrm{~cm}$ dan disiapkan terlebih dahulu dibiarkan sebelum ditanami bibit, lalu diamkan selama 2 hingga 3 hari dan kemudian masukkan campuran pupuk. (4) Untuk perawatan, lakukan penyiraman secara rutin (lakukan pemupukan susulan) hingga menjadi 
pohon dewasa (Gambar 1). Usahakan menggunakan pupuk organik.

Dalam proses penyerbukan, ada peranan penting dari serangga dan juga angin dimana hasil dari perkawinan silang tersebut menghasilkan buah kurma (5) Panen, pohon kurma jantan dan betina akan dapat dibedakan ketika pohon tersebut telah berbunga. Bunga yang terdapat pada pohon kurma betina berbentuk seperti bunga pohon kelapa (memiliki pentol). Sedangkan untuk pohon kurma jantan bunganya berwarna putih dan ukuran bunganya lebih kecil serta mengandung zat tepung. Ketika proses penyerbukan berhasil dan pohon kurma mulai berbuah, yang perlu diperhatikan selanjutnya adalah gangguan dalam proses pembuahan.

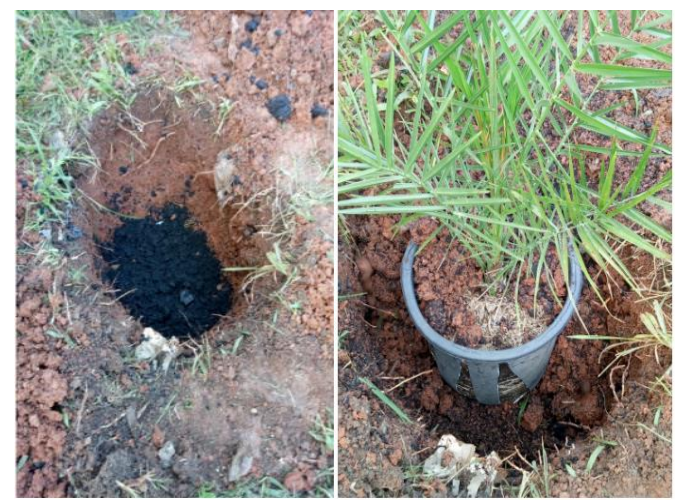

Gambar 1. Penanaman Kurma

Budidaya Pohon Tin (Ficus carica L.)

Tanaman ini merupakan salah satu tanaman yang sangat penting di dunia saat ini, seperti di Turki, Mesir, Maroko, Spanyol, Yunani, California,
Italia, Brasil dan tempat lain. F. Carica ada yang berasal dari Timur Tengah. Saat ini, buah tin banyak yang masih tumbuh liar di cekungan Mediterania Sekarang dibudidayakan pula di Australia, Cile, Argentina, serta Amerika Serikat.

Habitus berupa pohon, besar dan dapat tumbuh hingga $10 \mathrm{~m}$ dengan batang lunak berwarna abu-abu. Daunnya cukup besar dan berlekuk (3 atau 5 cuping). Bunga tin tidak tampak karena terlindung oleh dasar bunga yang menutup. Penyerbukan dilakukan oleh sejenis tawon khusus (seperti serangga yang menyerbuki jenis-jenis Ficus lainnya). Disebut buah adalah dasar bunga yang membentuk bulatan. Buahnya berukuran panjang tiga hingga $5 \mathrm{~cm}$, berwarna hijau. Beberapa kultivar berubah warna menjadi ungu jika masak. Pemanfaatan buah Tin dapat dimakan langsung, dikeringkan, atau dibuat selai. Buah yang dipetik harus segera dimanfaatkan karena tidak dapat disimpan lama (mudah rusak).

Hampir semua kultivar yang ditanam adalah hasilnya seleksi lama dan dikelola dengan memotong sebagai cara perbanyakan vegetatif. Ada beberapa metode untuk membudidaya buah tin ini, salah satunya adalah 
dengan cara mencangkok pohon tin (manmart.com/cara-budidaya-buah-tindan-beragam-manfaatnya/). Tahap yang harus dilakukan untuk budidaya buah tin dengan cara mencangkok dengan tahap-tahap yang harus dilakukan untuk mencangkok pohon yaitu: (1) Pertama, pilih pohon tin yang batangnya masih muda dan berkulit hijau, karena lebih cepat tumbuh dan akan lebih banyak menghasilkan buah. (2) Persiapkan plastik transparan dan juga cocopeat murni. (3) Lalu balutlah batang pohon yang ingin dicangkok dengan cocopeat yang sudah dibungkus dengan plastik transparan (panjang cangkokan cukup 10 sampai $15 \mathrm{~cm}$ ).(4) Ikat media cangkok pada bagian pangkal dan ujungnya dengan menggunakan tali.(5) Siram media cangkok setiap hari (penyiraman dilakukan melalui celahcelah yang sudah disiapkan sebelumnya) (6) Saat sudah 30 sampai 45 hari cangkok dimulai memiliki banyak peranakan, artinya cangkok sudah siap di potong dan dipindahkan ke media normal.

Cara kedua untuk metode budidaya buah tin adalah dengan metode stek batang. Cara ini tidak jauh berbeda dengan metode mencangkok yaitu: (1) Potong batang (cabang pohon)yang sudah berumur. Ciri-cirinya adalah pohon yang sudah mempunyai kulit berwarna coklat atau ungu dengan ukuran batang 10 sampai $15 \mathrm{~cm}$. (2) Batang yang di stek dipotong miring. (3) Setelah stek siap, kemudian semai di tempat persemaian yang sudah diberikan pasir atau cocopeat murni di dalamnya. (4) Bekas potongan bagian atas pada pohon tin yang dijadikan bahan stek harus dilapisi lilin. Tujuannya untuk mencegah kebusukan terjadi.(5) Siram hasil stek tadi setiap hari untuk menjaga tanah tetap lembab, dan (6) setelah 45 hari, pohon tin hasil stek sudah memiliki banyak batang. Artinya pohon tin tersebut sudah siap untuk dipindahkan ke lahan baru atau ke pot.

Bibit tanaman buah tin baik hasil cangkokan ataupun hasil stek lebih baik ditanam di dalam pot. Untuk menanam di dalam pot membutuhkan campuran tanah, cocopeat, kotoran kambing dan sekam mentah dengan perbandingan 1:1. Pohon tin ini pun mempunyai cara merawat yang khusus, karena tanaman ini berasal dari negara dengan cuaca panas.

\section{Budidaya Buah Bidara}

Tanaman ini dikenal dengan pelbagai sebutan didaerah seperti 
widara, dara, bukol, běkul, kok, kom, kon, bědara bidara, rangga, serta kalangga (Heyne, 1987). Sebutan di negara-negara lain di antaranya: Thailan menyebutnya phutsaa (ma tan), Vietnam menyebutnya tao (tao nhuc), Malaysia menyebutnya bidara (jujub atau epal siam). Philiphina menyebutnya manzanitas, Myanmar menyebutnya zee-pen, Kamboja menyebutnya putrea Laos menyebutnya than, (Latif, 1991).

Cara menumbuhkan daun bidara yang terbaik adalah di iklim hangat dan kering, namun dapat mentolerir turunnya musim hujan atau musim dingin. Pohon bidara yang tumbuh tidaklah sulit asalkan memiliki tanah berpasir dan gembur. Daun bidara ini berwarna hijau dengan tiga tulang daun yang sejajar. Daun ini juga tumbuh berpasangan pada sebuah tangkai sepanjang 8-15 $\mathrm{mm}$ (https://www.faunadanflora.com/.).

Bentuk tepinya cenderung bulat dan memiliki ujung yang lonjong. Daun Bidara diselimuti duri meski masih muda,. Di bagian ketiak daun terdapat bunga yang berwarna agak kuning. Panjangnya sekitar 1-2 cm dan terdapat 7-20 kuntum bunga. Jumlah mahkota ada 5, berbentuk sedikit cekung, sudip, serta membentuk sebuah lengkungan. Walaupun bentuknya kurang sangat menarik, perbungaan tersebut beraroma harum.

Daun bidara tidak spesifik tentang $\mathrm{pH}$ tanah tapi perlu ditanam di bawah sinar matahari penuh. Pohon itu bisa dibudidaya dengan biji atau tunas akar. Pohon bidara pensuplai nitrogen sebelum musim tanam membantu produksi buah. Walaupun pohon ini mentolerir kekeringan, air biasa membantu produksi buah. Tidak ada masalah penyakit yang diketahui dengan pohon ini (biasanya ulat kupukupu yang memakan daun.

Saat ini memasarkan produk tanaman surga menjadi peluang usaha potensial. Harga bibit buah surga ini cukup mahal menjadi daya tarik mempelajari usaha buah tin ini. Bidara dapat juga dibuat berbagai macam olahan mulai dari teh daun tubruk maupun celup, manisan, buah tin kering, selai, sirup, nastar, brownis, cuka hingga cokelat buah tin yang paling banyak digemari konsumen.

\section{Dampak Kegiatan}

Berdasarkan pengetahuan peserta terhadap pembinaan dan penyuluhan manajemen tanaman surgawi untuk meningkatkan kesejahteraan yaitu: 


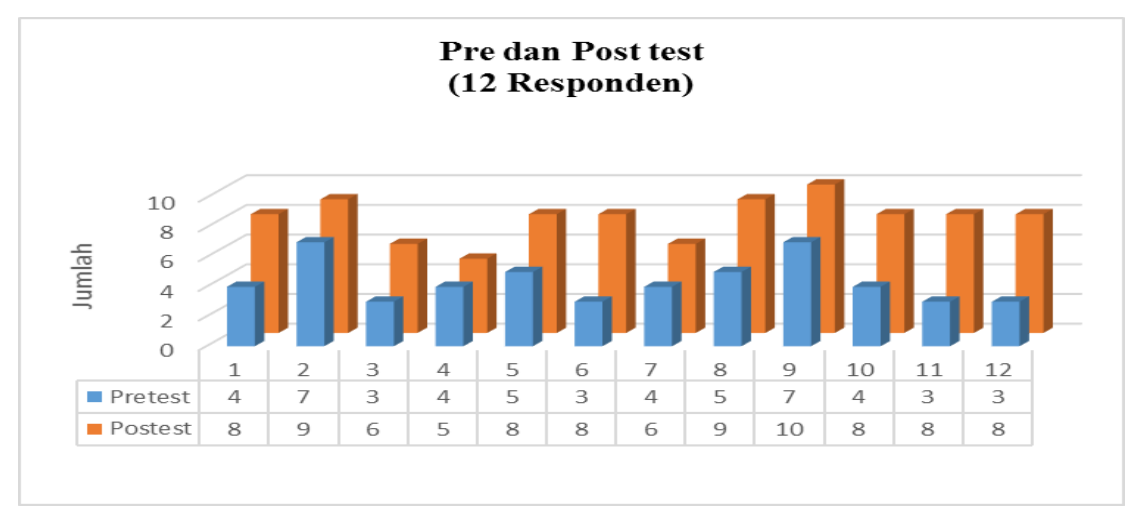

Gambar 2. Hasil pre dan postest peserta

Dari 7 (tujuh) indikator pertanyaan (Gambar 2) terkait pengetahuan manfaat tanaman surgawi yang diberikan sebanyak 12 orang peserta. Tampak pengetahuan yang diterima oleh peserta terjadi kenaikan dengan rata-rata hasil jawaban benar 4,33 (pre test) dan menjadi 7,75 (post test) jawaban. Hal tersebut menujukkan bahwa kegiatan ini cukup berhasil meningkatkan pengetahuan peserta (Nazwirman et al., 2019) Mengingat sebagian besar peserta memiliki tingkat pendidikan menengah kebawah. Proses sosialisasi yang dilakukan dengan penyuluhan dan praktik metode budidaya tanaman surga.

Dalam kegiatan yang dilaksanakan kerjasama Universitas Yarsi dan petugas kebersihan Banjar Wijaya Kota Tangerang. Diantara para peserta kegiatan sosialisasi dan budidaya tanaman surga (Gambar 3).
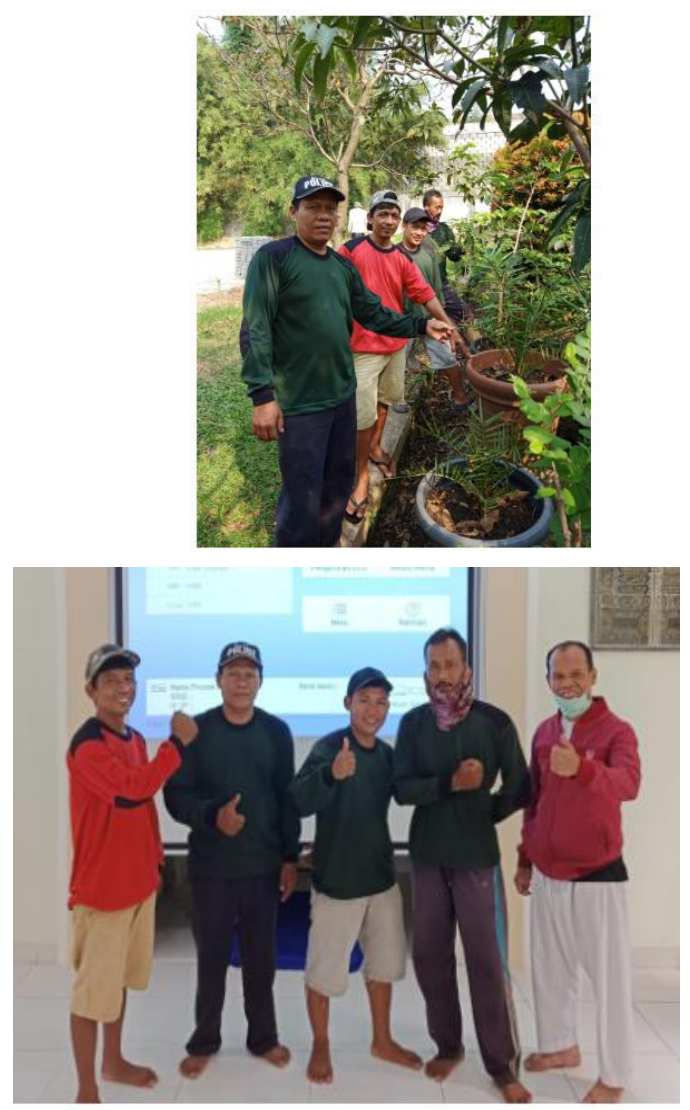

Gambar 3. Kegiatan pelaksanaan

Kegiatan penyuluhan dan pembinaan manfaat dan budidaya tanaman surgawi pada petugas kebersihan di lingkungan Perumahan 
Banjar Wijaya Kota Tangerang dilakukan dengan penjelasan tentang manfaat tanaman surgawi dan praktik peragaan budidayanya. Dalam kegiatan yang dilaksanakan kerjasama Universitas Yarsi dan petugas kebersihan. Peserta yang hadir sebanyak 12 orang peserta tidak termasuk panitia.

\section{KESIMPULAN}

Pemberian pembinaan dan penyuluhan dalam penanaman tanaman surgawi merupakan bagian dari Pengabdian pada Masyarakat yang berlokasi di Perumahan Banjar Wijaya Kota Tangerang. Kegiatan dimaksudkan untuk memberikan pengetahuan tentang manfaat-manfaat yang terkandung pada Kurma, Tin dan Bidara. Praktik dan pendampingan metode budidaya tanaman yang terkandung dalam Al Qur'an dan Sunnah nabi baik dengan metode stek atau mencangkok. Pelaksanaan kegiatan ini telah meningkatkan pengetahuan peserta. Dimasa datang dapat menghasilkan income tambahan bagi tenaga kebersihan di perumahan tersebut.

\section{UCAPAN TERIMA KASIH}

Ucapkan banyak terima kasih kepada Yayasan Universitas Yarsi dengan pendanaan yang diberikan. Anggota Pengabdian dan seluruh peserta petugas kebersihan Banjar Wijaya kota Tangerang.

\section{DAFTAR PUSTAKA}

Al-Quran Terjemahan. (2015). Departemen Agama RI. Bandung: CV Darus Sunnah.

Bentrad N, Gaceb, Benmalek Y and Rahmania F. (2017). Studies on Chemical Composition and Antimicrobial Activities of Bioactive Molecules from Date Palm (Phoenix Dactylifera L.) Pollens and Seeds. Afr J Tradit Complement Altern Med. 14 (3).

Garba, L. Muhammad Yusha'u and Adamu Yerima. (2013). Antibacterial Activity of Ethanol Extract of Phoenix dactyliferaLeaves against some Gram Negative Bacterial Isolates. Greener Journal of Biological Sciences. 3(6): 238-243.

HeYNE, K. (1987). Tumbuhan Berguna Indonesia, Jil. 3. Jakarta: Yay. Sarana Wana Jaya. (sebagai Zizyphus Jujuba Lamk.)

Hadits Riwayat Muslim RA

Hadits Riwayat Bukhari-Muslim

http.www.bps.go.id

https://money.kompas.com/read/2019/0 4/15/203514726/jelang-puasaimpor-kurma-hingga-pakaianjadi-meningkat, diunduh 8 September 2019.

https://ndb.nal.usda.gov/ndb/, diunduh 8 September 2019 
https://sentrabudidaya.com/tipsbudidaya-cara-menanam-kurma/, Diunduh 10 September 2019

http.www//manmart.com/carabudidaya-buah-tin-dan-beragammanfaatnya/, Diunduh 10 Septemberr 2019

https://www.faunadanflora.com/pandua n-lengkap-cara-budidaya-pohonbidara/, Diunduh 10 Septemberr 2019

LATIF, A.M.. (1991). Ziziphus mauritiana Lamk. In: Verheij, E.W.M. and Coronel, R.E. (Editors). Plant Resources of South-East Asia No. 2: Edible fruits and nuts. Pudoc,
Wageningen, The Netherlands, 310-312

Nazwirman, Juniarti Juniarti, Yurika Sandra. (2019). Peningkatan Peran Ibu Rumah Tangga Terhadap Pencegahan Sindroma Metabolik. Jurnal Pengabdian AlIkhlas. 4(2): 202-211

Rostini, Tintin, Muhammad Irwan Zakir, Rizqi Elmuna Hidayah. (2017). Peningkatan Produktivitas Kambing Di Kelompok Ternak Kambing Kecamatan Cempaka Kota Banjarbaru Kalimantan Selatan. Jurnal Pengabdian AlIkhlas. 3(1): 22-29. DOI: http://dx.doi.org/10.31602/jpai.v3 i1.922 